\title{
THE ROLE OF INDONESIAN MEDICAL DISCIPLINARY BOARD'S VERDICT ON MEDICAL DISCIPLINARY VIOLATION IN MEDICAL DISPUTES SETTLEMENT
}

\author{
Nayla Alawiya, Alef Musyahadah Rahmah, Nurani Ajeng Tri Utami \\ Universitas Jenderal Soedirman Purwokerto \\ E-mail: nayllaw86@gmail.com
}

\begin{abstract}
Whether there is medical disciplinary violation or not is decided by Indonesian Medical Disciplinary Board (MKDKI) according to the mandate of Article 55 of Law Number 29 Year 2004 on Medical Practice. Article 66 paragraph (3) of Law Number 29 Year 2004 also grants right for every person whose interest are violated by a doctor or dentist's act during their medical practice to report the alleged criminal offense to the authority or file a civil lawsuit to court. The provision potentially weakens MKDKI's verdict role in medical dispute settlement. The result shows that MKDKI in medical dispute settlement contribute to provide written real evidence. It can be medical dispute settlement by mediation, a report to the authority or a suit to court. The role of MKDKI's verdict is still hampered by several factors including law, law enforcement, facilities and cultural factors.
\end{abstract}

Keywords: medical dispute, doctors and dentists, disciplinary violations, the verdict role

\begin{abstract}
Abstrak
Ada atau tidaknya pelanggaran disiplin oleh dokter diputuskan oleh MKDKI berdasarkan amanat Pasal 55 Undang-Undang Number 29 Tahun 2004 tentang Praktik Kedokteran. Pasal 66 ayat (3) Undang-Undang Nomor 29 Tahun 2004 juga memberi hak kepada setiap orang yang kepentingannya dirugikan oleh tindakan dokter atau dokter gigi dalam menjalankan praktik kedokteran untuk melaporkan dugaan tindak pidana ke pihak yang berwenang atau mengajukan gugatan perdata ke pengadilan. Ketentu-an tersebut disinyalir dapat membuat putusan MKDKI kurang berperan dalam penyelesaian sengketa medik. Hasil penelitian menunjukkan bahwa peranan putusan MKDKI dalam penyelesaian sengketa medik adalah menjadi alat bukti surat, baik penyelesaian sengketa medik dengan cara mediasi, laporan ke pihak yang berwenang maupun gugatan ke pengadilan. Peranan putusan MKDKI masih terhambat oleh faktor hukum, faktor penegak hukum, faktor fasilitas dan faktor budaya.
\end{abstract}

Kata kunci: sengketa medik, dokter dan dokter gigi, pelanggaran disiplin, peranan putusan

Introduction

Every medical practicioner must serve health care based on medical standart according to the law and regulations. In fact, the health care provided by practicioner is always as expected. Medical practitioner's negligence frequently causes fatal impact such as disability, paralyzed, or even death. ${ }^{1}$

$\Omega \quad$ This article is the summary of the research result, funded by DIPA Universitas Jenderal Soedirman with contract Number 2239/UN23.14/PN/2016, March $2^{\text {nd }} 2016$.

1 Setya Wahyudi, "Tanggung Jawab Rumah Sakit terhadap Kerugian Akibat Kelalaian Tenaga Kesehatan dan Implikasinya", Jurnal Dinamika Hukum, Vol. 11 No. 3, September 2011, Purwokerto: Faculty of Law Universitas Jenderal Soedirman, page 505.
One of medical practicioners who has an important role in health care is doctor. Like common people, doctor might be be negligent or made mistakes sometimes which potentially cause violations of code of medical ethics, even it is possible to commit a violation of the legal norms. ${ }^{2}$ Patient and the family can complain the alleged disciplinary violation by doctor to Indonesian Medical Disciplinary Board (MKDKI). Article 64 of Law Number 29 Year 2004 on Medical Practice determines that MKDKI tasks include

\footnotetext{
Ni Luh Gede Yogi Arthani dan Made Emy Andayani Citra, "Perlindungan Hukum Bagi Pasien Selaku Konsumen Jasa Pelayanan Kesehatan yang Mengalami Malpraktek", Jurnal Advokasi FH Unmas, Vol. 3 No. 2, 2013, Denpasar: Faculty of Law Universitas Mahasaraswati, page 120.
} 
receiving complaint, examining, and deciding upon medical disciplinary violation case conducted by doctors or dentists. The provision is reinforced by Article 66 paragraph (1) of Law Number 29 Year 2004 on Medical Practices which states that whoever find out or their interests are harmed by doctors or dentists treatment during their medical practices, they may file a written complaint to Indonesian Medical Disciplinary Board.

The doctor treatment which is not based on the given standards violates medical disciplinary as well as harms patients or even considered a criminal offense. Besides complaining to MKDKI, patient and family have a right to file a civil lawsuit to court or report an alleged criminal offense to police department. The right is based on Article 66 paragraph (3) of Law Number 29 Year 2004 on Medical Practice which determines that the complaint should not eliminate the right of everyone to report any alleged criminal offense to the authority and/or sue for civil damages to trial.

Commonly, the patients will report a medical dispute to the police office or mas media when the dispute occurs. An unproven case often becomes sensational news since medical practicioner becomes the object of press for being socially punished which defame the medical practitione's reputation regardless preceeding the trial. ${ }^{3}$

In early 2014, a group of doctors, Dokter Indonesia Bersatu filed judicial review toward Article 66 paragraph (3) of Law Number 29 Year 2004 on Medical Practice to Indonesia Constitutional Court. The reason is the article causes doctor to be reported and convicted directly without MKDKI's recommendation. The lawsuit is motivated by doctor Ayu's case who was jailed due to the cassation verdict by the judge, Artdijo Alkotsar.

The court verdict that decided dr. Ayu and friends guilty motivated by the implementation of the code of ethics can be concluded that there are three impacts: The first is ju-

Dani Amalia Arifin, "Kajian Yuridis Tanggung Jawab Perdata Rumah Sakit Akibat Kelalaian dalam Pelayanan Kesehatan", Jurnal Idea Hukum, Vol. 2 No. 1, March 2016, Purwokerto: Magister Degree of Law, Faculty of Law Universitas Jenderal Soedirman, page 80. dicial impact. It needs judicial review related to the implementation of the proper code of ethics of professional which the norm is reformatio in melius; second, is sociological impact; it gives motivation to the role of Indonesian Medical Disciplinary Board (MKDKI); and the third is psychological impact; it aims to enchance the service quality as society's demand in accessing health care based the advance in science and technology. ${ }^{4}$

Chief of the Constitutional Court Judges determined that Article 66 Paragraph 3 is still needed in order to protect the patient legal rights. He assumed that the article is necessary to maintain the doctors' pride and dignity. Constitutional Court's decision showed that MKDKI's role is weak and it frightens doctor to make certain decision for patient. ${ }^{5}$ The provision of Article 66 Paragraph 3 of Law Number 29 Year 2004 implied that MKDKI's decision is not considered by the judge in settling a case, since there is no an article stating that every lawsuit should be through MKDKI to get the verdict.

Law enforcement is implemented by upholding function, duty and authorities of institution that has law enforcement duty based on proportion of their own scope. It also based on good cooperating system and support the mutual purpose. ${ }^{6}$ This article is aimed at explaining the role of MKDKI's verdict in medical dispute settlement and the factors that influence the role of MKDKI's verdict. Therefore, it will depict the proportion of MKDKI as an institution that should enforce the law and the importance of establishing cooperation system between MKDKI with other law enforcement institution in medical dispute settlement.

4 Henry P. Panggabean, “Penanganan Kasus Malpraktek yang Responsif dalam Sistem Peradilan Indonesia", Law Review UPH, Vol. 13 No. 3, March 2014, Tangerang: Universitas Pelita Harapan, page 357.

5 Redaksi detiknews, 20 April 2015, MK Putuskan Dokter Bisa Dipenjara Tanpa Rekomendasi MKDKI. Available on website http://news.detik.com/berita/2892693/mk-pu tuskan-dokter-bisa-dipenjara-tanpa-rekomendasi-mkdki, accesed on November 20 2015.

6 Tedi Sudrajat," Aspirasi Reformasi Hukum dan Penegakan Hukum Progresif Melalui Media Hakim Perdamaian Desa”, Jurnal Dinamika Hukum, Vol. 10 No. 3, September 2010, Purwokerto: Faculty of law Universitas Jenderal Soedirman, page 292. 


\section{Problems}

This Paper will discuss: first, how does the role of $M K D I$ verdict on medical disciplinary violation in medical dispute settlement?; second, what are the factors which influence the role of MKDI verdict on medical disciplinary violation in medical dispute settlement?

\section{Research method}

This is a research result which applied socio-juridical method and qualitative research approach. It is descriptive research by applying purposive sampling or criterian based selection in selecting informants. The data collection method was done by interviewing the vice president and secretary of MKDKI and literature review. In this research the data were analyzed by qualitative method and content analysis.

\section{Discussion}

The Role of MKDKI's Verdict on Medical Disciplinary Violation in Medical Dispute Settlement

The relation between patient and doctor in therapeutic agreement creates an agreement namely an attempt of medication. ${ }^{7}$ Rights and obligations implementation in medical practice could potentially raise a dispute. Dispute could be identified as a situation where someone wanted to force their will to another who confront them and hold an opposition. ${ }^{8}$ Dispute in medical practice is known as medical dispute, it is a dispute between the doctor and patient in providing health care. ${ }^{9}$

Medical dispute settlement must be through MKDKI in advance before it is reported to law enforcement institution since MKDKI is a profession judiciary instution. The settlement is

Bambang Sukarjono, "Liabilitas Hukum Pihak Rumah Sakit terhadap Pasien (Studi tentang Perlindungan Konsumen/ Pasien dan Tanggung Jawab Pihak Rumah Sakit dalam Transaksi Terapeutik pada Rumah Sakit Islam Siti Aisyah Kota Madiun)", Social, Vol. 10 No. 2, September 2009, Malang: STIE Malangkucecwara, page 32.

8 Faiz Mufidi dan Sri Pursetyowati, "Penyelesaian Sengketa Medik di Rumah Sakit", Jurnal Ilmu Hukum Wacana Paramarta, Vol. 8 No. 1, 2009, Bandung: Faculty of Law Universitas Langlangbuana, page 18.

9 Arif Nuryanto, "Model Perlindungan Hukum Profesi Dokter", Jurisprudence, Vol. 1 No. 1. July 2012, Surakarta: Muhammadiyah Universitas Surakarta, page 5. taken by a patient through court since he does not know about settlement of medical law processes. ${ }^{10}$ Law Number 29 year 2004 on medical practice explained that an institution which authorizes to decide a disciplinary violation by doctor or dentist occurs is Indonesian Medical Disciplinary Board (MKDKI). MKDKI only emphasizes on doctor or dentist proceeding with administrative sanction. Patient who feels harmed by the doctor or dentist can file a lawsuit based on Law Number 29 year 2004 on medical practice Article 66 paragraph 3 which determines that a complaint to MKDKI does not deprive the rights to report an alleged criminal offense towards authorities or file a civil suit to court.

Patient could ask for compensation by filing a civil suit to court because of medical disciplinary violation done by doctor or dentist. Viewed from the types of consequences for unlawful acts, especially towards human body, compensation would be given for the following reasons: firstly, economic loss (medical and hospital cost); secondly, injury or deformity toward victim's body; thirdly, physical pain; and fuorthly, mental pain (stress, depression, extreme hatred, anxiety etc. ${ }^{11}$

Doctor's treatment can be considered as criminal act or cause one's loss if they violate the profession discipline and operational procedural standard. Article 50 letter of Law Number 29 Year 2004 explained that doctor has the rights to receive law protection along with their duty based on profession and operational procedure standard. Disciplinary violation by doctor is particularly managed by MKDKI through court processes to make decision.

The verdict of MKDKI is obtained from court session based on Indonesian Medical Council Number 32 Year 2015 on Procedure of Case Treatment on Alleged Medical Disciplinary Violation. A procedure of alleged criminal offensive by doctors and dentists disciplinary violation is processed by MKDKI through several stages, they

10 Ananta Tantri Budi, "Upaya bantuan Faculty of Dentistry Universitas Airlangga, page. 6.

11 Bambang Heryanto, "Malpraktik Dokter dalam Perspektif Hukum”, Jurnal Dinamika Hukum, Vol. 10 No. 2, Mei 2010, Purwokerto: Faculty of Law Universitas Jenderal Soedirman, page 191. 
are: complaint stages; verification and clarification; first inspection; investigation; and discipline interrogation court session.

A judge verdict in court must meet justice demand which consist of three elements; legal security, justice and expediency. ${ }^{12}$ MKD$\mathrm{Kl}$ 's verdict as a result of doctor and dentist disciplinary violation court investigation processes also must fullfil those three elements. The manifestation of MKDKI's verdict is based on Soerjono Soekanto doctrine which explained that role is a dinamic aspect of status. When one does their rights and obligations along with his status, thus he has to carry out a role. ${ }^{13}$ The implementation of MKDKI's verdict role based on Robert B. Sedimen theory declares that there are three elements of working law, consist of law maker institution, law executive institution and the role holders. ${ }^{14}$

An interview with MKDKI concerned about the role of verdict and medical disciplinary violation revealed that MKDKI play roles in: first, providing a law protection for doctors and patients; second, enforcing doctor's discipline; third, assuring the health care quality by the doctor; fourth, serving as an evidence for reporting a case or lawsuit to authorities and court.

The interview with Indonesian Medical Disciplinary Board revealed that the role of MKDKI's verdict in providing legal protection for doctors and patients is proven by the MKDKI's verdict status which is absolute and binding for doctors. Disciplinary violation by doctor happens in therapeutic's bond agreement between doctors and patients, the verdict is issued by MKDKI as the institution which has the authorities based on law, and the verdict is obtained through hearing.

The role of MKDKI's verdict in giving legal protection for doctors and patient is based on

12 Fence M. Wantu," Mewujudkan Kepastian Hukum, Keadilan dan Kemanfaatan dalam Putusan Hakim di Peradilan Perdata", Dinamika Hukum journal, Vol. 12 No. 3, September 2012, Purwokerto: Faculty of Law Universitas Jenderal Soedirman, page 482.

13 Soerjono Soekanto, 1990, Sosiologi Suatu Pengantar, Jakarta: Rajawali Pers, page 114

14 Satjipto Rahardjo, 1980, Hukum dan Masyarakat, Bandung: Angkasa, page 27
Article 69 paragraph (1) Consitution Number 29 Year 2004 on Medical Practice which determines that MKDKI's verdict binds doctors, dentists and Indonesian Medical Council and Article 69 paragraph (2) which determines the verdict that has mentioned on paragraph (1) can be found unguilty or given disciplinary sanctions.

If the role of MKDKI's verdict in giving legal protection for doctors and patient is interpreted by Robert B. Seidmen's theory, MKDKI as law implementer produces a verdict on whether there is or not a disciplinary violation by doctors and gives sanction as response to role holders (i.e doctors and patients). Meanwhile if the role of MKDKI's verdict is interpreted by doctrine of Soerjono Soekanto, MKDKI's verdict which is absolute and binding for doctors, dentists, and Indonesian Medical Council, is obtained through hearing and the existence of sanction is considered as a form of the role of MKDKI's verdict in giving legal protection for doctors and patients.

The interview with MKDKI informs the role of MKDKI's verdict in disciplining doctors and dentists. It is shown from disciplining doctors who break the rule from verdict of disciplinary offense and the verdict of administrative sanction as one of MKDKI's duties. MKDKI's duty is aimed to protect citizen as health care recipients.

This is in line with Article 55 paragraph (1) of Medical Practice Law stating to uphold discipline of doctors and dentists in implementation of medical practice, MKDKI is formed. One of MKDKI's duties is to manage disciplinary violation of doctor and dentist case as it has been decided in Article 64 of Medical Practice Law, MKDKI's verdict as the role in disciplining doctors and dentists.

If the role of MKDKI's verdict in disciplining doctors and dentists is interpreted by Robert B. Seidmen's theory, then MKDKI as law enforcement bring in verdict about the existence of disciplinary offense by doctors and gives sanction as response to stakeholder (i.e doctors and patient) in order to give legal protection for doctors and patients. If the role of MKDKI's verdict is interpreted by doctrine of Soerjono Soe- 
kanto, then the verdict of MKDKI is as the result for implementation of duties such as re-ceiving complaints, checking and deciding dis-ciplinary offense doctors and dentist case which are submitted and also imposing sanction. Those are forms of MKDKI's role in disciplining doctors and dentists.

The interview result with MKDKI revealed that the role of MKDKI's verdict in ensuring the quality of health service by doctors and dentists is shown by the purpose of MKDKI's verdict in protecting people, improving the service quality and preserve the dignity of doctor. MKDKI's verdict about whether or not the disciplinary offense by doctors and dentists occurs is produced in order to ensure the quality of doctors and dentists' service.

The role of MKDKI's verdict in ensuring the quality of health service by doctors and dentists is based on Article 69 paragraph (2) Law Number 29 Year 2004 on Medical Practice which determines that the form of MKDKI's verdict can be found unguilty or given disciplinary sanction. The existence of sanction for the guilty doctors and dentists will minimalize the unstandard quality of health service. It shows that MKDKI's verdict contributes to ensure the quality of health service by doctors and dentists.

If the role of MKDKI's verdict in ensuring the quality of health service by doctors and dentists is interpreted by Robert B. Seidmen's theory, then MKDKI's as law enforcement makes verdict about the existence of disciplinary of fense and giving sanctions as the response for the role holders (i.e doctors and patients). If it is interpreted with doctrine of Soerjono Soekanto, then MKDKI's verdict is as the result from implementation of MKDKI's duties such as receiving complaints, checking and deciding proposed disciplinary offense doctors and dentist case and also giving sanction. Those are form of role of MKDKI in ensuring the quality of health service by doctors and dentists.

Then the interview also revealed that the role of MKDKI's verdict as evidence for lawsuit to authorities or civil action to court is shown from the status of its verdict. This status is nondepartment instution of state's verdict which is absolute and binding. Consequently, it must be obeyed by doctors and dentists; law enforcement agency acknowledge the existence of MKDKI's verdict by considering it as one of evidences.

MKDKI's verdict states the existence of disciplinary offense also sanctions for doctors and dentists who violate the law, then the verdict is obtained through hearing which is held by the authorized and competent institution as evidence in court, i.e documentative evidence. The verification by MKDKI and general court has the same process of proving.

If the role of MKDKI's verdict as the evidence in filing crime report to authority or civil action to court is interpreted by Robert B. Seidmen's theory, then MKDKI as law executive agent produces verdict about the existence of disciplinary offense by doctors and giving sanctions as the response to role holders (i.e doctors and patients) in order to get the evidence in filing and take action. If that role is interpreted by doctrine of Soerjono Soekanto, then MKDKI's verdict is as the result from implementation of MKDKI's duties such as receiving complaints, checking and deciding proposed disciplinary of doctors and dentist case and also giving sanction. Those are form of its role as one of the evidence in doing so.

Based on those four roles of MKDKI's verdict, the role of MKDKI's verdict in medical dispute settlement is as documentary evidence which can be used in any settlement of medical dispute, whether it is mediation, crime report to authorities or civil action to court.

Factors which influence the Role of Indonesian Medical Disciplinary Board Verdict on Medical Disciplinary Violation in Medical Dispute Settlement

The research results show that the role of MKDKI's verdict on medical disciplinary violation in medical dispute settlement is affected by some supporting factors such as: competence of MKDKI's commissioner in making verdict, integrity of MKDKI's commissioner in performing their job and the presence of trial facility. These factors tend to give positive contribution 
to the role of MKDKI's verdict on medical disciplinary violation in medical dispute settlement.

Aside from the supporting factors, the role of MKDKI's verdict on medical disciplinary violation in medical dispute settlement is also affected by several hindering factors: time trial restriction, witness who postpones attending the trial, uncooperative expert witness, abundant cases, unsupportive facilities, undisciplined management of institution, conflict of interest. These factors tend to give negative contribution to the role of MKDKI's verdict on medical disciplinary violation in medical dispute settlement.

If those facts is interpreted based on Soerjono Soekanto's theory, the implementation of law is greatly influenced by its own law, law enforcement, and society as subject of the law, facilities, and cultural factors. ${ }^{156}$ Therefore, it can be depicted that the time trial restriction is categorized as the law factor; conflict of interest is categorized as the law enforcement; abundant cases, witness who postpones attending the trial, uncooperative expert witness, undisciplined management of institution are categorized as the cultural factors, and unsupportive facilities is categorized as facilityies factor. In the meantime, doctor as society as subject of the law factor does not show as significant hurdle.

\section{Conclusion}

The role of MKDKI's verdict in medical dispute settlement is used as written evidence that can be employed in every medical dispute settlement by mediation, a report to the authority or a suit to court. The role of MKDKI's verdict is still hampered by the law, law enforcement, facilities, and cultural factors. Meanwhile, the society as subject of the law factor which is doctor in this case does not give any significant hurdle.

\section{Suggestion}

15 Soerjono Soekanto, 1983, Faktor-Faktor yang Mempengaruhi Penegakan Hukum, Jakarta: Rajawali Pers, page 10.
Necessary measures can be taken to strengthen the role of MKDKI's verdict as real written evidence in medical dispute settlement including to build coordination between MKDKI and other law enforcement institutions which relates to medical dispute settlement, such as; BPRS, Police, Prosecutor and Judge.

\section{References}

Arifin, Dani Amalia. "Kajian Yuridis Tanggung Jawab Perdata Rumah Sakit Akibat Kelalaian dalam Pelayanan Kesehatan". Jurnal Idea Hukum. Vol. 2 No. 1. March 2016. Purwokerto: Magister Degree of Law Fac-ulty of Law Universitas Jenderal Soedir-man;

Arthani, Ni Luh Gede Yogi dan Made Emy Andayani Citra. "Perlindungan Hukum Bagi Pasien Selaku Konsumen Jasa Pelayanan Kesehatan yang Mengalami Malpraktek". Jurnal Advokasi FH Unmas. Vol. 3 No. 2. 2013. Denpasar: Faculty of Law Universitas Mahasaraswati;

Budi, Ananta Tantri "Upaya bantuan hukum dokter gigi dalam menghadapi sengketa medis". Jurnal PDGI. Vol. 59 Number 1. January 2010. Surabaya: Faculty of Dentistry Universitas Airlangga;

Heryanto, Bambang. "Malpraktik Dokter dalam Perspektif Hukum". Jurnal Dinamika Hukum. Vol. 10 No. 2. Mei 2010. Purwokerto: Faculty of Law Universitas Jenderal Soedirman;

Mufidi, Faiz dan Sri Pursetyowati. "Penyelesaian Sengketa Medik di Rumah Sakit". Jurnal Ilmu Hukum Wacana Paramarta. Vol. 8 No. 1. 2009. Bandung: Faculty of Law Universitas Langlangbuana;

Nuryanto, Arif. "Model Perlindungan Hukum Profesi Dokter". Jurisprudence. Vol. 1 No. 1. Juli 2012. Surakarta: Universitas Muhammadiyah Surakarta;

Panggabean, Henry P. "Penanganan Kasus Malpraktek yang Responsif dalam Sistem Peradilan Indonesia". Law Review UPH. Vol. 13 No. 3. March 2014. Tangerang: Universitas Pelita Harapan;

Rahardjo, Satjipto. 1980. Hukum dan Masyarakat. Bandung: Angkasa;

Redaksi detiknews, 20 April 2015, MK Putuskan Dokter Bisa Dipenjara Tanpa Rekomendasi MKDKI. Tersedia di website http:// news.detik.com/berita/2892693/mk-pu 
tuskan-dokter-bisa-dipenjara-tanparekomendasi-mkdki, access on November $20^{\text {th }} 2016$.

Soekanto, Soerjono 1983. Faktor-Faktor yang Mempengaruhi Penegakan Hukum. Jakarta: Rajawali Pers;

1990. Sosiologi Suatu Pengantar. Jakarta: Rajawali Pers;

Sukarjono, Bambang. "Liabilitas Hukum Pihak Rumah Sakit terhadap Pasien (Studi tentang Perlindungan Konsumen/Pasien dan Tanggung Jawab Pihak Rumah Sakit dalam Transaksi Terapeutik pada Rumah Sakit Islam Siti Aisyah Kota Madiun)". Sosial. Vol. 10 No. 2. September 2009. Malang: STIE Malangkucecwara;
Sudrajat, Tedi." Aspirasi Reformasi Hukum dan Penegakan Hukum Progresif Melalui Media Hakim Perdamaian Desa". Jurnal Dinamika Hukum. Vol. 10 No. 3. September 2010. Purwokerto: Faculty of Law Universitas Jenderal Soedirman;

Wahyudi, Setya. “Tanggung Jawab Rumah Sakit terhadap Kerugian Akibat Kelalaian Tenaga Kesehatan dan Implikasinya". Jurnal Dinamika Hukum. Vol. 11 No. 3. September 2011. Purwokerto: Faculty of Law Universitas Jenderal Soedirman;

Wantu, Fence M." Mewujudkan Kepastian Hukum. Keadilan dan Kemanfaatan dalam Putusan Hakim di Peradilan Perdata". Jurnal Dinamika Hukum. Vol. 12 No. 3. September 2012. Purwokerto: Faculty of Universitas Jenderal Soedirman. 